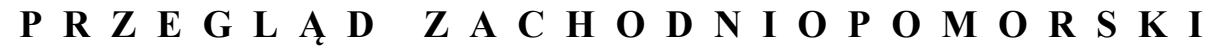 ROCZNIK XXXIV (LXIII) ROK 2019 ZESZYT 3
}

\section{$\begin{array}{llllllll}\mathbf{A} & \mathbf{R} & \mathbf{T} & \mathbf{Y} & \mathbf{K} & \mathbf{U} & \mathbf{L} & \mathbf{Y}\end{array}$}

\author{
Katarzyna Rembacka \\ ORCID: 0000-0002-4009-3390 \\ Instytut Pamięci Narodowej \\ e-mail: katarzyna.rembacka@ipn.gov.pl
}

\section{NIEDOBORY ROKU 1945 I ZACHODNIOPOMORSKIE POMYSŁY NA ICH PRZEZWYCIĘŻANIE. SPRAWA ,BERLIŃSKICH ZAKUPÓW”}

Słowa kluczowe: Okręg Pomorze Zachodnie, niedobory, handel, spekulacja, waluta, nadużycia, granica, Berlin, Szczecin, motoryzacja, 1945 rok

Keywords: West Pomerania, shortages, commerce, profiteering, currency, misappropriation, border, Berlin, Szczecin, motorisation, 1945

Jak dotąd sprawa „,berlińskich zakupów”, czyli sprowadzania niemieckich towarów do Polski przez zachodniopomorskich urzędników, nie została opisana w literaturze, co łączyć można przynajmniej z kilkoma czynnikami. Teoretycznie rozegrała się ona w stosunkowo krótkim czasie (październik 1945), jednak informacje z nią związane odnajdziemy zarówno przed, jak i po wskazanej dacie. Ponadto wątki na jej temat są rozproszone w różnych wspomnieniach, dokumentach czy archiwach i nie stanowią - poza jednym przypadkiem - jednolitego zbioru - a i ten jest nader skromny. Niewielka liczba akt nie powinna jednak stanowić o wartości badawczej opisywanego zjawiska - jest ono bowiem egzemplifikacją trudności występujących m.in. w sektorze motoryzacyjnym, z jakimi borykały się polskie władze różnego szczebla, czego pochodną były aprowizacyjne problemy nękające ogół społeczeństwa. Jest ono także przykładem na to, jak szybko przejmowane były przez system określone sfery życia, jak je regulowano, 
a ostatecznie monopolizowano. Zachodniopomorski region odgrywał przy tym pierwszoplanową rolę, gdyż to właśnie tam - ze względu na bliskość okupowanej i ogarniętej chaosem niemieckiej stolicy - rodziły się i były wdrażane przeróżne handlowe pomysły. Pomysły, których realizacja narażona była na niebezpieczeństwa rozmaitego kalibru - od napaści i rabunku mienia, poprzez międzyresortowe konflikty, do sankcji orzekanych przez określone gremia. „Berlińskie zakupy” to także jeden z przykładów na to, jak wielką improwizacją była tużpowojenna rzeczywistość.

Szczecińska Stunde Null, czyli „godzina zero” rozpoczęła się w kwietniu 1945 roku. Towarzyszący jej stan niepewności ciągnął się dłużej niż w innych miastach przyłączonych do Polski po II wojnie światowej. Jak zanotował pierwszy polski powojenny prezydent Szczecina Piotr Zaremba: „w dniu 5 lipca 1945 roku skończyło się szczecińskie prowizorium, trwające sześćdziesiąt osiem dni, od 28 kwietnia począwszy"1. Tyle tylko, że jeszcze w trakcie konferencji tzw. wielkiej trójki odbywającej się kilkadziesiąt dni później w Poczdamie, strona brytyjska zaprezentowała mapę, na której kolorem różowym oznaczony został Szczecin „jako najbardziej sporny”2. Sporna była nie tylko jego ostateczna przynależność państwowa, ale również precyzyjne wyznaczenie zachodniej granicy Polski, która ostatecznie ustalona miała być podczas planowanej konferencji pokojowej. Konferencji, do której nie doszło. Prowizorium zatem trwało w najlepsze, choć bardziej już dotyczyło owej linii oddzielającej terytorium polskie od niemieckiego, zaś super arbitrem wyznaczającym jej przebieg byli Sowieci - to za ich zgodą i pod ich nadzorem odbył się we wrześniu 1945 roku terenowy objazd, którego celem było precyzyjne zakreślenie linii granicznej, co i tak nie zapobiegło licznym błędom przy jej wytyczaniu³. Nowy podział spowodował m.in. przerwanie

1 P. Zaremba, Pierwszy szczeciński rok 1945, Poznań 1970, s. 205.

2 T. Marczak, Granica zachodnia w polskiej polityce zagranicznej w latach 1944-1950, Wrocław 1995, s. 104.

3 „1945 wrzesień 21, Schwerin (Mecklenburg) - Porozumienie polsko-radzieckie zawarte w Schwerinie w sprawie wykonania decyzji poczdamskiej dot. granicy państwowej na zachód od Szczecina i przekazania Polsce terenów położonych na tym obszarze”. T. Białecki, Wytyczenie granicy państwowej na zachód od Szczecina i Świnoujścia w 1945 roku, „Acta Cassubiana" 2006, nr 8, s. 44. 
wielu dotąd funkcjonujących połączeń drogowych, a także linii kolejowej. Problemem był także brak profesjonalnego zabezpieczenia granicy. Co prawda Wojska Ochrony Pogranicza powołano rozkazem z 13 września 1945 roku, jednak „zasadnicze zakończenie prac nad organizacją oddziału i przejęcie przez niego formalnie ochranianego odcinka granicy" na obszarze Pomorza Zachodniego nastąpiło dopiero dwa miesiące później5. I choć jednym z zadań WOP było zapobieganie przewożeniu lub przenoszeniu towarów przez granicę z pominięciem przepisów celnych, zjawisko przemytu na dużą skalę było faktem ${ }^{6}$.

Z powyższymi problemami próbowali uporać się polscy administratorzy tych ziem. Dokładny przebieg granicy uwzględniający wspomniane wyżej ,przecięcia" odtworzyli urzędnicy Wydziału Pomiarów Urzędu Pełnomocnika RP na Okręg Pomorze Zachodnie. Opis sporządzony 30 września 1945 roku przesłany został do Ministerstwa Spraw Zagranicznych ${ }^{7}$. Akt graniczny ustalający przejęcie przez Polskę wskazanych terenów na 4 października 1945 roku, wraz z załączoną radziecką mapą sztabową, do Warszawy osobiście zaś odwiózł okręgowy pełnomocnik (późniejszy wojewoda) Leonard Borkowicz ${ }^{8}$, który być może właśnie podczas tego pobytu podjął rozmowy dotyczące przeprowadzenia operacji mającej „wybitnie niesolidny charakter".

Solidni i wpływowi więc musieli być ci, którym plan Borkowicz przedstawiał - stąd cała plejada ministerialnych dygnitarzy, wśród których znaleźli się: Konstanty Dąbrowski (minister skarbu), Zygmunt Modzelewski (wiceminister spraw zagranicznych), Jerzy Sztachelski (minister aprowizacji i handlu) i Władysław Wolski (wiceminister administracji publicznej), a także niemający wówczas ministerialnej teki, ale za to bardzo wpływowy, Edward Ochab. Właściwie ze

4 B. Sitarz, Trudne początki. Powiat szczeciński 1945-1950, Police 2012, s. 39.

5 J. Prochwicz, Organizacja Wojsk Ochrony Pogranicza wrzesień 1945 - grudzień 1945, „Biuletyn. Problemy Ochrony Granic” 2010, nr 44, s. 32.

${ }^{6}$ M. Stefaniak, Działalność aparatu represji na zachodnim pograniczu Polski $w$ latach 1945-1950, Szczecin 2008, s. 142-144.

7 Archiwum Ministerstwa Spraw Zagranicznych (dalej AMSZ), Biuro Spraw Kongresowych, z. 18, w. 27, t. 411, Opis granicy zachodniej Rzeczypospolitej Polskiej na odcinku Świnoujście-Gryfin, Koszalin, 30.09.1945 r., k. 38.

8 Archiwum Akt Nowych (dalej AAN), Ministerstwo Administracji Publicznej (dalej MAP), sygn. 2391, Notatka o przebiegu pertraktacji w sprawie ustalenia linii granicznej na zachód od Odry sporządzona przez P. Zarembę, b.d., k. 89.

9 AAN, Komitet Centralny Polskiej Partii Robotniczej (dalej KC PPR), sygn. 295/VII 256, List Leonarda Borkowicza do wiceministra spraw zagranicznych Zygmunta Modzelewskiego, Koszalin, 20.10 .1945 r., k. 7. 
wszystkimi Borkowicz współpracował już wcześniej, a z Ochabem i Sztachelskim łączyły go co najmniej serdeczne relacje. Nic zatem dziwnego, że szczegóły berlińskich interesów omawiane były podczas „,nocnych rozmów rodaków”"10. A spraw do omówienia było niemało, zważywszy na to, że planowana akcja miała być przeprowadzona z rozmachem i miała na poły nielegalny charakter.

Wymyślono zaś rzecz następującą - za niemieckie marki (reichsmarki), ludzie wysyłani przez Borkowicza do Berlina kupować mieli rozmaite towary, najczęściej luksusowe. Handlowe możliwości okupowanej niemieckiej stolicy dostrzegało i wykorzystywało wielu. Robili to Amerykanie, Brytyjczycy, Rosjanie czy Polacy, co obrazowo przedstawił Jerzy Kochanowski:

Podczas tzw. okresu niczyjego - kiedy stare pensje już nie były wypłacane, a nowe jeszcze nie, stare kartki żywnościowe nieważne, a nowych jeszcze nie wydawano, zapas gotówki się wyczerpał, a banki jeszcze nie działały, spiżarnie i sklepowe półki opustoszały - czarny rynek pomagał przetrwać ${ }^{11}$.

Pomagał także dokonywać operacji prowadzących do szybkiego pozyskiwania wartościowego mienia, którego zbywanie prowadziło do uzyskiwania określonych korzyści - zarówno zawodowych, jak i osobistych.

Swoją szansę dostrzegł m.in. Henryk Krochmalski, naczelnik wydziału aprowizacji i handlu okręgowego urzędu w Koszalinie, który przed przyjazdem na Pomorze Zachodnie był pełnomocnikiem Rządu do Spraw Rzeczowych i Wojskowych z ramienia Ministerstwa Aprowizacji i Handlu ${ }^{12}$. Musiał być człowiekiem przedsiębiorczym - to przecież on zapewniał żywność i inne podstawowe artykuły zarówno polskiej, jak i niemieckiej ludności pozostającej na Pomorzu Zachodnim. Latem 1945 roku wyjeżdżał służbowo do Berlina w celu zorganizowania dla znajdujących się tam Polaków stołówki i domu noclegowego. Pewnie widział, tak jak i Zaremba, że na Alexanderplatz czy w ruinach Reichstagu ,ruch handlowy duży, handel kwitnie”13. Krochmalski ściśle współpracował z Borkowiczem i cieszył się jego zaufaniem, co poskutkowało powierzeniem mu berlińskich interesów.

${ }^{10}$ Tamże.

${ }^{11}$ J. Kochanowski, Tylnymi drzwiami. „Czarny rynek” w Polsce 1944-1989, Warszawa 2015, s. 47.

${ }^{12}$ Kierowca Petnomocnika Rządu (1), www.sedina.pl (dostęp 20.03.2019).

${ }^{13}$ P. Zaremba, Dziennik 1945, Szczecin 1996, s. 85, 90-91. 
Sytuację jednak komplikował fakt, że od czerwca 1945 roku zarówno obrót „zagranicznymi środkami płatniczymi”, jak i ich wywóz za granicę był w Polsce zakazany ${ }^{14}$. Obwieszczeniu ministra skarbu nie towarzyszyły jednak właściwe regulacje prawne dotyczące polityki pieniężnej na ziemiach zachodnich i północnych. O ile bowiem dekret z 5 lutego 1945 roku stanowił o „deponowaniu i wymianie marek niemieckich na terenach Rzeczypospolitej Polskiej, wyzwolonych spod okupacji po dniu 6 stycznia 1945 r."15, o tyle projekt stosownego dekretu odnoszący się do tzw. Ziem Odzyskanych opracowany jesienią tego roku w Ministerstwie Skarbu, nigdy nie został uchwalony ${ }^{16}$. Polski złoty dostarczany był na te obszary z dużym opóźnieniem i w niewystarczającej ilości, co boleśnie odczuwali na sobie m.in. Polacy wracający do ojczyzny zza Odry ${ }^{17}$. Złoty nie był zatem w stanie wyrugować z obiegu niemieckich marek, na wymianę których nie zdecydowały się władze centralne ${ }^{18}$. Zresztą gromadzeniem tej waluty zainteresowana była ludność niemiecka planująca wyjazd bądź przymusowo wysiedlana na Zachód.

O sytuacji tej rychło zwiedzieli się spekulanci walutowi, którzy uzyskawszy za bezcen $\mathrm{w}$ głębi kraju wycofane marki niemieckie oraz wykorzystując swoistą sytuację graniczną w naszym mieście, przedostawali się przez Szczecin do Niemiec i tam dokonywali zakupów na wielką skalę. Niektórzy z nich zaopatrywali szczecińskich Niemców przed ich powrotem do ojczyzny [sic! - dop. K.R.] w potrzebne im marki ${ }^{19}$.

${ }^{14}$ Stosowne obwieszczenie ministra skarbu opublikowano 20.06 .1945 r. J. Kochanowski, Tylnymi drzwiami..., s. 282.

${ }^{15}$ Dz. U. 1945 , nr 5, poz. 17 i 18.

${ }^{16}$ Z. Landau, Reformy walutowe na ziemiach polskich w 1945 roku, „Kwartalnik Historyczny" 1968 , nr 1, s. 77.

${ }^{17}$ „W związku z powrotem repatriantów należy też zwrócić uwagę na wielką bolączkę ich, bolączką tą jest brak polskich pieniędzy. Brak ten zmusza ich do sprzedaży różnych rzeczy osobistych za marne grosze, co dla niektórych jest bardzo przykre, a spekulantom daje szerokie pole do popisu". Archiwum Instytutu Pamięci Narodowej w Szczecinie (dalej AIPN Sz), sygn. 008/34, t. 2, Sprawozdanie dekadowe Miejskiego Urzędu Bezpieczeństwa Publicznego w Szczecinie za okres od 27.10. do 7.11.1945 r., k. 6.

${ }^{18}$ Zdaniem Roberta Furtaka ,wymiany marek na Ziemiach Odzyskanych prawdopodobnie nie dokonano z powodu nasilającej się inflacji w kraju. Operacja taka musiałaby bowiem spowodować dalszy wzrost emisji pieniądza". R. Furtak, Reformy pieniężne w Polsce w latach 1944-1950, „Annales Universitatis Mariae Curie-Skłodowska. Sectio H, Oeconomia” 1995/1996, nr 29/30, s. 178.

${ }^{19}$ P. Zaremba, Pierwszy szczeciński..., s. 225. 
Pod wpływem tych obserwacji, w połowie lipca 1945 roku, szczeciński prezydent Piotr Zaremba przedstawił Borkowiczowi propozycję, aby to Narodowy Bank Polski wykorzystując „bezużytecznie leżące w kasach kraju” marki, uruchomił w Berlinie ,własną placówkę zakupu” ${ }^{20}$. Nawet jeśli - jak pisze Zaremba - przedstawiony przez niego wniosek został zaakceptowany i oznaczono go kryptonimem „Akcja B”, nic nie wskazuje na to, aby doszło do jego rzeczywistej realizacji. Wymowne mogą być sprawozdania sporządzane przez pracowników szczecińskiego oddziału NBP z tego okresu, w których sprawy walutowe skomentowano nie dość, że lakonicznie, to jeszcze zupełnie inaczej niż widział to Zaremba:

Jedyną obiegową walutą na terenie Szczecina jest złoty polski. Marki niemieckie jak i marki okupacyjne nie znajdują się w obiegu, jak również czarna giełda nie notuje nimi żadnych obrotów ${ }^{21}$.

Najbardziej jednak wymownym dowodem na to, że plan „Akcji B” poddano modyfikacji lub całkowicie zarzucono są „,berlińskie zakupy” realizowane według koncepcji i pod nadzorem Leonarda Borkowicza. Przy czym zaznaczyć należy, że specjalnym emisariuszem dysponującym kilkudziesięciomilionowym budżetem został Krochmalski.

Jak już wcześniej wspominano, tematem „berlińskich zakupów” Borkowicz zainteresował przynajmniej kilku strategicznych partnerów w Warszawie, którzy byli niezbędni nie tylko do sformalizowania interesów mających ,pozornie taki »skomplikowany « charakter"22, ale także do pozyskania pieniędzy. Pierwszą osobą, która wyraziła zgodę na realizację przedsięwzięcia był Konstanty Dąbrowski kierujący ministerstwem skarbu. To właśnie ten resort 23 października 1945 roku otrzymał od Borkowicza ponad 80 męskich i blisko 30 damskich 18-karatowych, złotych zegarków ${ }^{23}$. Zachodniopomorski pełnomocnik jednocześnie informował o wcześniejszym zakupie wyrobów tekstylnych, trykotowych, pończoszniczych

${ }^{20}$ Tamże, s. 225-226.

${ }^{21}$ [1945 lipiec, Szczecin] - Pierwsze sprawozdanie z organizacji Oddziału NBP w Szczecinie, w: Sektor prywatny, spółdzielczy oraz państwowy na Pomorzu Zachodnim w latach 1945-1949 w świetle sprawozdań Narodowego Banku Polskiego, wstęp, wybór i oprac. P. Chrobak, „Źródła do Dziejów Pomorza Zachodniego”, t. XVI, Szczecin 2015, s. 34.

${ }^{22}$ AAN, KC PPR, sygn. 295/VII - 256, Pismo Leonarda Borkowicza, Koszalin, 2.11.1945 r., k. 5 .

${ }^{23}$ Tamże, Protokół przejęcia kosztowności ze Skarbca Wojewódzkiego w Koszalinie spisany w Skarbcu Narodowego Banku Polskiego w Warszawie, 23.10.1945 r., k. 16. 
czy galanteryjnych, które rozprowadzone zostały między pracowników podległego mu urzędu, a także pośród „Władz Okręgu Pomorza Zachodniego”24, ale nie tylko. ,... wyroby tekstylne: jak pończochy, skarpetki, flanele, swetry, płótno koszulowe itd." przekazał Borkowicz również do powiatów, „ze szczególnym uwzględnieniem Związków Zawodowych w Szczecinie"25. Wydaje się jednak, że dla Warszawy bardziej niż trykoty istotne były cenne „drobiazgi” i samochody.

A tych ostatnich brakowało wszędzie i wszystkim. W dramatycznej sytuacji postawiony był Borkowicz, który wiosną 1945 roku zorganizować miał administrację na Pomorzu Zachodnim. Wysyłając w teren kolejne grupy, świeżo mianowanym pełnomocnikom obwodowym zadawał takie samo pytanie:

Co kolega zrobi natychmiast po przyjeździe do swojego powiatu? Odpowiedzi są różne (...) Stwierdzam sucho, że nikt nie udzielił trafnej odpowiedzi, bo pierwszą czynnością pełnomocnika będzie odesłanie mi samochodu, abym mógł wysłać następną ekipę ${ }^{26}$.

Potwierdzenie takiego stanu rzeczy znajdujemy w piśmie naczelnika Okręgowego Urzędu Samochodowego z 30 kwietnia, który stwierdził, że „na obszar 41 powiatów Pełnomocnik dysponuje 4 samochodami ciężarowym i 1 samochodem osobowym"27. Warto pokreślić, że pozyskiwanie aut na terenie Pomorza Zachodniego było ograniczone, gdyż oprócz rabunkowej działalności Armii Czerwonej czy Wojska Polskiego, wraz z przesuwającym się frontem wyruszały tam ,zespoły tzw. szperaczy z zadaniem wyszukiwania dla jednostek i instytucji państwowych samochodów, które dawało się jeszcze uruchomić" ${ }^{28}$. Niemniej

${ }^{24}$ Tamże, List Leonarda Borkowicza do ministra skarbu, Konstantego Dąbrowskiego, Koszalin, 20.10.1945 r., k. 10.

${ }^{25}$ Archiwum Państwowe w Szczecinie (dalej APS), Komitet Wojewódzki Polskiej Partii Robotniczej w Szczecinie (dalej KW PPR), sygn. 34, Sprawozdanie Komitetu Polskiej Partii Robotniczej Pomorza Zachodniego w Koszalinie za okres od dnia 15.10. do 15.11.1945 r. dla Komitetu Centralnego PPR w Warszawie, k. 87.

${ }^{26}$ Wspomnienia Borkowicza o pierwszych dniach urzędowania w Pile, w: Pierwszy wojewoda szczeciński. Dokumenty i komentarze (1945-1949), oprac. Z. Chmielewski, K. Kozłowski, Szczecin 1986, s. 19.

${ }^{27}$ APS, Urząd Wojewódzki Szczeciński (dalej UWS), sygn. 4895, Pismo Okręgowego Urzędu Samochodowego do Naczelnego Dyrektora Państwowego Urzędu Samochodowego, Piła, 30 IV 1945 r., k. 1. Za udostępnienie materiałów bardzo dziękuję Pawłowi Miedzińskiemu.

${ }^{28}$ H. Wilk, Między pragmatyzmem a oczekiwaniami. Społeczeństwo, władza i samochody w Polsce 1945-1970, Warszawa 2017, s. 78. 
przyrost taboru kołowego postępował, choć liczby nie oszałamiały - w lipcu polska administracja posiadała 79 samochodów, z czego 60 było na „chodzie”29. Interesująca sytuacja nastąpiła później. Otóż według ,zestawienia numerów próbnych wydanych in blanco na zlecenie Pełnomocnika Rządu” Okręgowy Urząd Samochodowy w Koszalinie przekazał tymczasowe rejestracje na 64 samochody, z czego 46 trafiło do Borkowicza ${ }^{30}$. Być może jeden z samochodów zawiózł Krochmalski do Warszawy dla Zygmunta Modzelewskiego, aby przekazać go jako „próbę (nie bez wartości)” dotychczasowego powodzenia berlińskich interesów ${ }^{31}$.

O tym, że berlińskie interesy musiały się już toczyć wcześniej, świadczy rozszerzenie zakresu działania Krochmalskiego. Borkowicz prosił Modzelewskiego o przyznanie mu paszportu „względnie innego dokumentu”, umożliwiającego przemieszczanie się po strefie amerykańskiej w Niemczech w celu „rewindykacji mienia, należącego do morskiego miasta Szczecina, wywiezionego w swoim czasie przez Niemców”32. Równocześnie napisał do Jerzego Sztachelskiego, szefa Ministerstwa Aprowizacji i Handlu o zwolnienie swojego posłańca ze stanowiska naczelnika, tłumacząc zmianę powierzeniem mu obowiązków związanych z częstymi wyjazdami poza województwo ${ }^{33}$. Najważniejszym jednak dowodem na to, że zachodniopomorscy urzędnicy obracali niemieckimi markami i kupowali towary na tamtejszym rynku jest fragment listu Borkowicza do ministra Dąbrowskiego: „Równocześnie proszę o przekazanie do mojej dyspozycji na dalsze zakupy [podkr. - K.R.] 100.000.000 (sto milionów) marek niemieckich"34. Przy wymianie według oficjalnego kursu byłoby to $50 \mathrm{mln}$ zł.

Z wnioskowanej kwoty Borkowicz otrzymał w sumie 22,5 mln zł, które miały być wymienione na marki w Narodowym Banku Polskim. Stosowną informację przekazał zachodniopomorskiemu pełnomocnikowi Władysław Wolski, podsekretarz stanu w Ministerstwie Administracji Publicznej. Wolski poczynił

${ }^{29}$ APS, UWS, sygn. 4895, Dekadowe sprawozdanie o stanie liczebnym i technicznym taboru Okręgu Pomorze Zachodnie za I dekadę lipca 1945 r., k. 25.

${ }^{30}$ Tamże, Zestawienie numerów próbnych wydanych in blanco na zlecenie Pełnomocnika Rządu, Koszalin, 19.10.1945 r., k. 39.

${ }^{31}$ AAN, KC PPR, sygn. 295/VII - 256, List Leonarda Borkowicza do wiceministra spraw zagranicznych Zygmunta Modzelewskiego, Koszalin, 20.10.1945 r., k. 7.

32 Tamże.

${ }^{33}$ Tamże, List Leonarda Borkowicza do ministra aprowizacji i handlu, Jerzego Sztachelskiego, Koszalin, 20.10 .1945 r., k. 8.

${ }^{34}$ Tamże, List Leonarda Borkowicza do ministra skarbu, Konstantego Dąbrowskiego, Koszalin, 20.10.1945 r., k. 10. 
równocześnie dwa ważne zastrzeżenia - po pierwsze uczynił Borkowicza „osobiście odpowiedzialnym za właściwe zużytkowanie tych pieniędzy”, a po drugie zalecił mu ,jak najdalej posuniętą ostrożność” wobec handlowej działalności Krochmalskiego ${ }^{35}$. Skłoniły go do tego informacje, jakie miał, a zważywszy na jego wielce prawdopodobną współpracę z NKWD i wysokie stanowisko w Resorcie Bezpieczeństwa Publicznego PKWN, dostęp do źródeł mógł mieć ułatwiony ${ }^{36}$. I to wiarygodnych bądź przekonujących źródeł, o czym świadczy aresztowanie Krochmalskiego, do którego doszło 30 października, po odebraniu przez niego czeków na $20 \mathrm{mln}$ marek (25 mln otrzymał wcześniej), w momencie gdy opuszczał gmach Ministerstwa Administracji Publicznej mieszczący się przy ul. Rakowieckiej 4. W związku z tym Borkowicz wysłał alarmujący list do któregoś ze swoich ustosunkowanych przyjaciół, z prośbą o pomoc i interwencję. Musiała być to osoba pozostająca dotąd poza kręgiem włączonym w „berlińskie zakupy”, co wynika z treści pisma. Po krótkim opisie sprawy Borkowicz prosił o zainteresowanie się nią, ponieważ „Krochmalski ma dla województwa czeki na większe sumy pieniędzy i Krochmalski jest człowiekiem uczciwym"37. Interwencja się powiodła i aresztowany urzędnik został wkrótce uwolniony, co najprawdopodobniej pozwoliło mu dość szybko - i nielegalnie - opuścić Polskę ${ }^{38}$.

Czy zatem udało się wykorzystać przyznane przez Warszawę pieniądze i czy miasto nad Szprewą nadal pozostawało dla polskich urzędników handlowym eldorado? Odpowiedź odnajdziemy m.in. w meldunku sporządzonym przez Sztab 3 Oddziału Wojsk Ochrony Pogranicza w Szczecinie:

\footnotetext{
${ }^{35}$ Tamże, List Władysława Wolskiego do Leonarda Borkowicza, Warszawa, 27.10.1945 r., k. 6 .

${ }^{36}$ T.P. Rutkowski, Sprawa Antoniego Piwowarczyka - Władysława Wolskiego, „Zeszyty Historyczne" 2005, z. 153, s. 131-137; zob. też K. Banaś, Władysław Wolski. Meandry kariery komunistycznego działacza, Łódź 2019, s. 35-40. k. 5 .

${ }^{37}$ AAN, KC PPR, sygn. 295/VII - 256, List Leonarda Borkowicza, Koszalin, 2.11.1945 r.,

${ }^{38}$ „Wracając do Krochmalskiego, Starczewski [naczelnik wydziału społeczno-politycznego Urzędu Wojewódzkiego w Szczecinie - dop. K.R.] podaje, że w 1946 r. [powinno być w 1945 r. - dop. K.R.] był on aresztowany w Warszawie. Borkowicz wyjechał do Warszawy i następnego dnia po jego powrocie przyjechał również do Szczecina Krochmalski, który wkrótce wyjechał zagranicę”. AAN, Kolekcja akt różnej proweniencji, sygn. 1/122, Leonard Borkowicz, Notatka informacyjna wiceministra bezpieczeństwa publicznego W. Lewikowskiego w sprawie Borkowicza Leonarda, Warszawa, 4.01.1950 r., k. 223. Należy zaznaczyć, że nie odnaleziono akt sprawy Henryka Krochmalskiego i nie ma żadnych dokumentów na jego temat $\mathrm{w}$ archiwum IPN.
} 
Do dnia 9 grudnia 1945 r. był w D-wie wielki natłok przedstawicieli firm, urzędów i różnych przedsiębiorstw, którzy posiadali rozkazy wyjazdu do Berlina w celu zakupu aut, maszyn do pisania itp., jak też towarów tekstylnych. Rozkazy wyjazdu były wystawiane przez Pełnomocnika Rządu na Pomorze Zachodnie Okręg Szczecin, na podstawie których D-two WOP udzielało wiz na przekroczenie granicy. Od dnia 10 grudnia 1945 r. udziela się wiz wyłącznie na podstawie przedłożenia paszportu zagranicznego wystawionego przez Ministerstwo Spraw Zagranicznych ${ }^{39}$.

Z możliwością uszczelnienia/zamknięcia granicy w Koszalinie liczono się już w październiku, dlatego tamtejszym władzom zależało na sprawnym i szybkim ściąganiu kupowanych na zachodzie towarów. Nie ukrywano zresztą tego, a wiadomość o tym, że ,zakupione inwestycje techniczne oraz towary w Berlinie milionowych wartości są narażone na niemożność ściągnięcia"40 m.in. ze względu na brak paliwa, spowodowała natychmiastową reakcję kierownika Oddziału Materiałów Pędnych w Koszalinie. „Niniejszym informuję, że w dniu dzisiejszym wysyłam cysternę 2500 litrów benzyny, która przeznaczona jest dla celów ściągnięcia sprzętu samochodowo-warsztatowego zakupionego w Berlinie"41. Dodajmy, że przekazana równocześnie informacja o komunikacyjnym paraliżu Szczecina spowodowanym brakiem paliwa, pozostała bez odpowiedzi ${ }^{42}$.

Powyższe wskazuje na dużą dynamikę ,,berlińskich zakupów”, przy czym wspomniani w meldunku WOP ,przedstawiciele” być może korzystali z innych

${ }^{39}$ Archiwum Straży Granicznej (dalej ASG), Pomorska Brygada WOP, sygn. 180/7, Meldunek sytuacyjny nr 4. Sztab 3 Oddziału WOP w Szczecinie, 21.12.1945 r., k. 128. Za udostępnienie materiału bardzo dziękuję Dominikowi Radeckiemu.

${ }^{40}$ APS, UWS, sygn. 4899, Pismo Pełnomocnika Państwowego Urzędu Samochodowego na Pomorze Zachodnie do Centrali Produktów Naftowych, Koszalin, 26.10.1945 r., k. 43.

${ }^{41}$ Tamże, Pismo kierownika Oddziału Materiałów Pędnych, Koszalin, 27.10.1945 r., k. 45.

${ }^{42}$ Nie był to jedyny wypadek ignorowania bardzo trudnej sytuacji w Szczecinie. Dokładnie w tym samym czasie, czyli w październiku 1945 r., istniało realne zagrożenie wybuchu strajku generalnego spowodowanego niewypłacaniem wynagrodzeń pracownikom sektora publicznego. Prośby kierowane do Warszawy o przekazanie kilku milionów zł zostały bez odpowiedzi. W tej sytuacji „,zastępca prezydenta Szczecina, Józef Maciejowski zdecydował się dokonać jawnego »napadu na bank« - o zamiarze tym poinformował prezesa oddziału banku, miejscowy urząd bezpieczeństwa, przedstawicieli partii i stronnictw politycznych. Zawiadomił o tym nawet premiera polskiego rządu. Gotówkę w wysokości $5 \mathrm{mln}$ zł przeznaczoną na wypłatę zaległych wynagrodzeń podjął Maciejowski 15 października". K. Rembacka, Leonard Borkowicz (1912-1989). Biografia polityczna, praca doktorska napisana pod kierunkiem prof. J. Eislera w Instytucie Historii Polskiej Akademii Nauk, Warszawa 2019, mps, s. 302. 
środków aniżeli te, które pozyskał Borkowicz ${ }^{43}$. Jego rola w opisywanym procederze trudna jest jednak do przecenienia, a przywołany meldunek wskazuje na jego znaczącą rolę oraz wiedzę o całym przedsięwzięciu. O tym, że uległo ono rozszerzeniu na inne instancje dowiadujemy się także z rozmaitych sprawozdań czy protokołów różnych gremiów. I tak, podczas posiedzenia Egzekutywy Komitetu Wojewódzkiego Polskiej Partii Robotniczej postanowiono oddelegować jednego z członków ,jako wojażera w sprawach zakupów samochodu ciężarowego i materiałów tekstylnych w Berlinie z ramienia Województwa" ${ }^{44}$. Interesujący jest przypadek działalności Narodowego Banku Polskiego, którego esencję stanowił konflikt ze szczecińskim Urzędem Bezpieczeństwa. Otóż w listopadzie bank wysłał do stolicy Niemiec swoich pracowników w celu zakupu ,partii samochodów osobowych dla Ministerstwa Skarbu i Centrali Narodowego Banku Polskiego"45. Zakupione mercedesy i ople gromadzono w szczecińskim oddziale banku, zaś „całą tę manipulację autami od dłuższego czasu obserwowali” miejscowi funkcjonariusze UB. Najpierw 31 grudnia, a następnie 1 stycznia 1946 roku, pod pozorem kontroli, ,przemocą przy pomocy swoich samochodów wyciągnęli kilka samochodów z autogarażu Banku”46. Ze stosowną interwencją wystąpił m.in. naczelnik Okręgowego Urzędu Samochodowego, ppłk. Jerzy Wodecki, kierując pisma z opisem sprawy do wielu instytucji ${ }^{47}$. Odzyskiwanie „zarekwirowanych” 12 samochodów trwało jednak co najmniej do maja, a te które były zwracane nosiły ,ślady złośliwych i celowych uszkodzeń" ${ }^{\text {"48 }}$.

43 „Szmuglem zajmowali się, na mniejszą lub większą skalę, nie tylko mieszkańcy nowego pogranicza. W warunkach powszechnego chaosu i korupcji władze graniczne, mimo teoretycznie obowiązujących paszportów, co najmniej do końca 1945 r. respektowały przeróżne przepustki i zezwolenia, wydawane przez rozmaite, nie zawsze państwowe instytucje". J. Kochanowski, Zanim powstała NRD. Polska wobec radzieckiej strefy okupacyjnej Niemiec 1945-1949, Wrocław 2008, s. 44.

${ }^{44}$ APS, KW PPR, sygn. 10, Protokół z zebrania Egzekutywy Komitetu Wojewódzkiego PPR, Koszalin, 27.11.1945 r., k. 31.

${ }^{45}$ APS, Komisja Specjalna do Walki z Nadużyciami i Szkodnictwem Gospodarczym, Delegatura w Szczecinie (dalej Delegatura KS), sygn. 79, Streszczenie wniesionych skarg do Komisji Specjalnej, Szczecin, 8.03.1946 r., k. 4.

${ }^{46}$ Tamże.

${ }^{47}$ APS, UWS, sygn. 4891, Pisma naczelnika Okręgowego Urzędu Samochodowego na Pomorze Zachodnie, ppłk. Jerzego Wodeckiego, k. 19-39.

${ }^{48}$ Tamże, Protokół inspektora Biura Kontroli przy Prezydium Krajowej Rady Narodowej płk. Wiktora Romańskiego, Szczecin, 9.02.1946 r., k. 42; Pisma naczelnika Okręgowego Urzędu Samochodowego na Pomorze Zachodnie, ppłk. Jerzego Wodeckiego do Prokuratora Wojskowego Sądu Rejonowego w Szczecinie, Szczecin, 11.05.1946 r., k. 29. 
Zresztą aktywność wszelkiego rodzaju służb w tropieniu osób prowadzących handlową działalność była coraz większa. W obiektywie bezpieki znalazł się dyrektor Dróg Wodnych w Szczecinie, Giendaszek, który w Berlinie kupił „4 samochody w tym jeden ciężarowy, na ogólną sumę 209 tys. marek”49. Sprawę tę prowadziła Sekcja Morska Miejskiego Urzędu Bezpieczeństwa, która wszczęła poszukiwanie aut. Na początku 1946 roku szczecińskie UB prowadziło także sprawę „rozpracowania agenturalnego na PKS pod kryptonimem »Auto«"50. W tym wypadku śledzono ludzi z kierownictwa przedsiębiorstwa, którzy jeździli do stolicy Niemiec, gdzie kupowali samochody, a następnie je sprzedawali. „Należy zaznaczyć, że inż. Radlewski i jego wujek sprzedają wozy DKW ${ }^{51}$ w Koszalinie, $»$ Framo $\aleph^{52}$ w Szczecinie $\mathrm{i} » Z$ itroeny w Połczynie" ${ }^{53}$. Nielegalny był zarówno handel autami, ich przemyt, jak i obrót markami, który uznawano wówczas za walutowe spekulacje. Sprawy osób prowadzących „niedozwolony handel walutą” traktowano jako przestępstwo i kierowano do rozpatrzenia przez sąd okręgowy ${ }^{54}$.

Nie bez znaczenia było również utworzenie szczecińskiej Delegatury Komisji Specjalnej do Walki z Nadużyciami i Szkodnictwem Gospodarczym, co stało się 30 stycznia 1946 roku, „choć za faktyczną datę rozpoczęcia jej działalności” należy uznać 9 marca 1946 roku $^{55}$. Wśród jej rozlicznych zadań znalazło się także zwalczanie szabrownictwa, łapownictwa i spekulacji ${ }^{56}$. Doniesienia o licznych

${ }^{49}$ AIPN Sz, sygn. 008/34, t. 2, Sprawozdanie Sekcji Morskiej za okres od 6.12. do 16.12.1945 r., k. 32.

${ }^{50}$ Tamże, Sprawozdanie dekadowe za okres od 17.02. do 27.02.1946 r. Miejskiego Urzędu Bezpieczeństwa Publicznego, k. 101.

${ }^{51}$ Dampfkraftwagen.

52 Marka wzięła swoje imię od nazwy niemieckiej firmy Frankenberg und Motorenwerke.

${ }^{53}$ AIPN Sz, sygn. 008/34, t. 2, Sprawozdanie dekadowe za okres od 17.01. do 27.01.1946 r. Miejskiego Urzędu Bezpieczeństwa Publicznego, k. 77.

${ }^{54}$ AIPN Sz, sygn. 008/34, t. 1, Sprawozdanie dekadowe za okres 16.09. do 26.09.1945 r. Sekcji VIII Miejskiego Urzędu Bezpieczeństwa Publicznego w Szczecinie, k. 78.

${ }^{55}$ J. Macholak, Delegatura Komisji Specjalnej do Walki z Nadużyciami i Szkodnictwem Gospodarczym w Szczecinie 1946-1954. Organizacja i działalność, w: Działalność Delegatury Komisji Specjalnej do Walki z Naduzyciami i Szkodnictwem Gospodarczym w Szczecinie w latach 1945-1954. Materiaty z konferencji naukowej z 20 marca 1998 r., red. Z. Chmielewski, Szczecin 1998, s. 36.

${ }^{56}$ M. Żukowski, Działalność i organizacja Delegatury Komisji Specjalnej do Walki z Nadużyciami i Szkodnictwem Gospodarczym w Szczecinie oraz Koszalinie w latach 1946-1954, „Przegląd Zachodniopomorski” 2002, nr 2, s. 87. 
handlowych wyjazdach do stolicy Niemiec złożył do Delegatury pracownik Wydziału Społeczno-Politycznego UW.

Naświetla fakt ob. Kosior Stefan, że bardzo [wielu - dop. K.R.] ludzi wyjeżdża pod różnym pretekstem do Berlina, np. z Banku, czy po kupno lekarstw, czy ksiądz rzekomo do swojego Arcypasterza, czy nawet Naczelnik Wydziału, Ociesza ${ }^{57}$.

Sprawy te jednak były na tyle zagmatwane, że po pismach z żądaniem złożenia stosownych wyjaśnień kierowanych m.in. do prezydenta Szczecina ${ }^{58}$, sukcesywnie je umarzano ${ }^{59}$.

Wszystko to stanowiło jedynie echo właściwych „berlińskich zakupów”, o których Borkowicz twierdził, że tylko „pozornie mają taki »skomplikowany« charakter" ${ }^{\prime 0}$. Sprawa jednak była niezwykle zagmatwana, a przyczynił się do tego także i zachodniopomorski pełnomocnik. To przecież na jego kategoryczne żądanie Okręgowy Urząd Samochodowy wydał kilkadziesiąt numerów próbnych in blanco. „Wydawane numery próbne powinny być zwracane a samochody rejestrowane. Działo się jednak inaczej (...)”. Jak wyliczono, wydano w sumie 82 numery, z których ,zgłoszono w OUS do 2 stycznia 1946 r. zaledwie 8 samochodów, a 74 nie, a śladu $31 \mathrm{w}$ dokumentach w ogóle brak"61. I choć widziano, że samochód marki Chrysler przekazany został Romanowi Zambrowskiemu, a Modzelewski otrzymał samochód osobowy Hanomag, to nie udało się ustalić w czyich rękach znalazła się większość aut.

Potwierdziła to także przysłana z Warszawy na kontrolę szczecińskiej placówki inspektor Komisji Specjalnej, Wera Srokowska. W sporządzonym przez nią sprawozdaniu możemy przeczytać następujące zdanie: „Poważnym a nierozpracowanym zagadnieniem jest sprawa nadużyć członków byłej Grupy Operacyjnej

${ }^{57}$ APS, Delegatura KS., sygn. 79, Streszczenie wniesionych skarg do Komisji Specjalnej, Szczecin, 8.03.1946 r., k. 3.

${ }^{58}$ APS, Delegatura KS, sygn. 69, Protokół z posiedzenia Komisji Specjalnej, Szczecin 7.04.1946 r., k. 2.

${ }^{59}$ Tamże, Protokół z posiedzenia Komisji Specjalnej, Szczecin, 4.09.1946 r., k. 36. Na tym samym posiedzeniu umorzono także sprawę ,przeciwko ks. Świetlińskiemu o sprzedaż samochodu nabytego w Berlinie", k. 34.

${ }^{60}$ AAN, KC PPR, sygn. 295/VII - 256, Pismo Leonarda Borkowicza, Koszalin, 2.11.1945 r., k. 5.

${ }^{61}$ APS, Delegatura KS., sygn. 79, Streszczenie wniesionych skarg do Komisji Specjalnej, Szczecin, 8.03.1946 r., k. 4a. 
Krochmalskiego"62. I choć Władysław Wolski za wielomilionowe zakupy osobiście odpowiedzialnym czynił Borkowicza, podkreślając że ,pieniądze te objęte są budżetem i będą kontrolowane jak wszystkie inne pozycje budżetowe" ${ }^{93}$, nie zapobiegło to nadużyciom. Wymowna jest lapidarna konstatacja szczecińskich członków Komisji Specjalnej, że odnośnie do zakupionych samochodów „żadnych akt zdawczo-odbiorczych nie ma" ${ }^{64}$. Z problemem ustalania sprawców dokonywanych wówczas przestępstw borykała się również Polska Misja Repatriacyjna w Berlinie. Jak pisał jej szef Zdzisław Bibrowski:

Angielska policja aresztowała polskiego oficera ze Szczecina w związku z kupnem kradzionego samochodu. W sprawę zamieszany był także pułkownik polski. Nazwisk niestety nie udało się ustalićc5.

Czy zatem ktoś poniósł konsekwencje wielce prawdopodobnej defraudacji publicznych pieniędzy i „zagubienia” co najmniej kilkudziesięciu maszyn? Wydaje się, że wojewódzcy urzędnicy (za wyjątkiem Borkowicza) zaangażowani w opisywany proceder wykorzystali dogodny dla siebie moment i uciekli za granicę. Tak przynajmniej opisywali to ich następcy, składający zeznania w 1950 roku. Jeden z nich, Bronisław Starczewski, do 1947 roku kierujący pracami Wydziału Społeczno-Politycznego ,naświetlał ich szabrowniczą działalność, stałe kursowanie między Berlinem, Szczecinem a Warszawą, przewożenie z Berlina brylantów i złota itp." ${ }^{\prime 6}$ Starczewski został wyrzucony z pracy przez Borkowicza, w związku z czym jego doniesienia mogły być przesadzone, tym bardziej, że za ówczesne nadużycia oskarżał właśnie wojewodę, niemniej podobne rewelacje głosił także

${ }^{62}$ AAN, Komisja Specjalna do Walki z Nadużyciami i Szkodnictwem Gospodarczym, sygn. 107, Sprawozdanie z inspekcji Delegatury w Szczecinie odbytej w dniach 23.04.29.04.1946 r. przez inspektor Srokowską, Warszawa, 2.05.1946 r., k. 2.

${ }^{63}$ AAN, KC PPR, sygn. 295/VII - 256, List Władysława Wolskiego do Leonarda Borkowicza, Warszawa, 27.10.1945 r., k. 6.

${ }^{64}$ APS, Delegatura KS., sygn. 79, Streszczenie wniesionych skarg do Komisji Specjalnej, Szczecin, 8.03.1946 r., k. 4a.

${ }^{65} 1945$ grudzień 13 - Pismo szefa PMR w Berlinie Z. Bibrowskiego do MAP w sprawie nielegalnego przekraczania granicy przez obywateli polskich, w: Polska - Niemcy Wschodnie. Wybór dokumentów, t. 1: Polska wobec Radzieckiej Strefy Okupacyjnej Niemiec maj 1945 - październik 1949, red. J. Kochanowski, K. Ziemer, wstęp i wybór J. Kochanowski, oprac. A. Krajewski, M. Mazurek, Warszawa 2006, s. 79.

${ }^{66}$ AAN, Kolekcja akt różnej proweniencji, sygn. 1/122, Leonard Borkowicz, Notatka informacyjna wiceministra bezpieczeństwa publicznego W. Lewikowskiego w sprawie Borkowicza Leonarda, Warszawa, 4.01.1950 r., k. 224. 
szczeciński wicewojewoda Czesław Studnicki. Twierdził, że Borkowicz miał do swojej dyspozycji specjalny fundusz, którym dowolnie rozporządzał. Stanowiło go $200 \mathrm{mln}$ marek wydawanych na zakup cennych przedmiotów. Z kolei szef Wojewódzkiego Urzędu Bezpieczeństwa Publicznego Jan Olkowski przekazał do Warszawy informację, że „Borkowicz przed wyjazdem ze Szczecina, na pożegnalnym bankiecie, obdarzył swego sekretarza, sekretarkę i woźnego złotymi zegarkami »Stopper«"67.

Wiarygodność powyższych informacji jest jednak dyskusyjna - zbierano je bowiem na polecenie wiceministra bezpieczeństwa publicznego Wacława Lewikowskiego, prowadzącego w 1950 roku postępowanie przeciwko Borkowiczo$w^{68}{ }^{6}$. Tak upływ czasu, a także pobudzające wyobraźnię setki mln marek wypaczały rzeczywisty obraz, który i tak trudny jest do precyzyjnego odtworzenia. Sam Borkowicz, składając wyjaśnienia Bolesławowi Bierutowi, napisał:

Z mojej inicjatywy, za pozwoleniem tow. Gomułki i tow. Dąbrowskiego jeździli ludzie do Berlina i kupowali za marki towary, które sprowadzali do Polski. Stanowczo odrzucam wszelkie w tej sprawie oskarżenia. Rola moja ograniczała się do ogólnego kierownictwa ${ }^{69}$.

I chyba rzeczywiście tak było, zważywszy na to, że Ministerstwo Bezpieczeństwo Publicznego zaniechało badania tego wątku.

„Berlińskie zakupy” prowadzone z dużą intensywnością jesienią 1945 roku z pewnością były autorskim pomysłem pierwszego szczecińskiego wojewody, Leonarda Borkowicza. Nie oznacza to jednak, że podobny proceder ograniczał się tylko do Pomorza Zachodniego. Za 600 tys. marek zakupiono w radzieckiej strefie okupacyjnej auta i motocykle, pieniądze zaś skonfiskowane zostały jeńcom przetrzymywanym w obozie Świętoszów (Neuhammer) na Śląsku ${ }^{70}$. Jak pisze Jerzy Kochanowski, działalność ta prowadzona m.in. przez mjr. Michała Fejgmana, naczelnika Wydziału Zakupów Departamentu III MBP i jego zastępcy,

${ }^{67}$ Tamże, k. 228.

${ }^{68}$ Więcej na ten temat zob. K. Rembacka, Wykluczony, skarcony, zmarginalizowany? Zatamanie kariery politycznej Leonarda Borkowicza w 1950 roku-studium przypadku, w: Elity komunistyczne w Polsce, red. M. Szumiło, M. Żukowski, Warszawa-Lublin 2015, s. 503-521.

${ }^{69}$ AAN, Kolekcja akt różnej proweniencji, sygn. 1/122, Leonard Borkowicz, List do Przewodniczącego Polskiej Zjednoczonej Partii Robotniczej, towarzysza Bolesława Bieruta, Praga, 1.03.1950 r., k. 39.

${ }^{70}$ J. Kochanowski, $W$ polskiej niewoli. Niemieccy jeńcy wojenni w Polsce 1945-1950, Warszawa 2001, s. 53. 
kpt. Aleksandra Trzcinka, wynikać mogła z tego, że „pracowali [oni - dop. K.R.] częściowo na własną rękę, częściowo zaś dla MBP, kupując dla niego samochody i części zamienne do nich"ᄁ1. Spekulacyjna fala, która zalała niemiecką stolicę późną jesienią 1945 roku, przynosiła „za sobą najbardziej wrogą dla Państwa [polskiego - dop. K.R.] propagandę"72. I choć zalew wszelkiej maści handlarzy szukających dla siebie szansy na zarobek napływał z całej Polski, największy „potok spekulacji” płynął z Pomorza Zachodniego. Zdaniem Bibrowskiego, tworzący go ludzie potrafili zakładać filie swoich przedsiębiorstw w Berlinie, co „może wpłynąć szkodliwie na gospodarkę finansową Polski”73.

Raport szefa PMR zbiegł się z momentem faktycznego zakończenia „berlińskich zakupów". Borkowicz próbował nadać im legalny wyraz, przekonując do ich realizacji przedstawicieli wielu ministerstw, co znalazło swoje odbicie w zachowanej dokumentacji. Nie ukrywał także ich „wybitnie niesolidnego charakteru". Równocześnie prowadzenie tej wielkiej handlowej operacji powierzył człowiekowi, który w ostatecznym rozrachunku zawiódł jego zaufanie i którego najzwyczajniej w świecie trudno było kontrolować. A właśnie o kontrolę i monopol chodziło. Od 1946 roku zarówno władze partyjne, jak i instytucje rządowe szukały sposobów na sprowadzanie do kraju towarów deficytowych i pozyskiwanie dewiz, stąd pomysł szefa Polskiej Misji Wojskowej w Berlinie Jakuba Prawina na utworzenie w tym mieście Polskiego Domu Handlowego. Stąd także działalność kierownika Wydziału Organizacyjnego PPR Franciszka Mazura, który „rozpoczął organizowanie w niektórych krajach Europy Zachodniej Ameryki Południowej, a także w Stanach Zjednoczonych sieci kontrolowanych przez partię przedsiębiorstw handlowych"74. Stąd w końcu pomysły wywiadu na zdobywanie pozabudżetowych środków finansowych ${ }^{75}$.

Choć trudno podać rzeczywiste efekty „berlińskich zakupów”, to można przyjąć, że do warszawskich dygnitarzy, a także pracowników zachodniopomorskich instytucji popłynęły rozmaite towary. Przypomnijmy, że w powojennej Polsce większość artykułów spożywczych (ale i np. wyroby dziewiarskie)

\footnotetext{
${ }^{71}$ Tamże, s. 54, przyp. 126.

${ }^{72} 1945$ grudzień 13 - Pismo szefa PMR w Berlinie Z. Bibrowskiego do MAP..., s. 79.

${ }^{73}$ Tamże.

${ }^{74}$ W. Bagieński, Wywiad cywilny Polski Ludowej w latach 1945-1961, t. 2, Warszawa 2017, s. 356.

75 Tamże, s. 354-370.
} 
była reglamentowana, co i tak nie zaspakajało podstawowych potrzeb ludności ${ }^{76}$. Przypomnijmy także, że w 1945 roku przeciętna pensja oscylowała w graniach 1000 zł, zaś jeszcze w połowie 1946 roku blisko 50\% wynagrodzenia wypłacane było w naturze ${ }^{77}$. Zatem sposób premiowania ludzi, jaki stosował Borkowicz nie odbiegał od normy pozwalając zarazem niwelować skutki niedoborów ${ }^{78}$. Dotyczyło to także sektora motoryzacyjnego, który stosunkowo szybko odbudowywał swoje straty. W grudniu 1945 roku - według oficjalnych danych - w Polsce było 19 tys. pojazdów samochodowych. Jak podaje Hubert Wilk, od końca wojny „liczba samochodów jeżdżących po polskich drogach zwiększyła się niemal trzykrotnie"79. Być może wśród nich znalazły się także maszyny sprowadzone w ramach „,berlińskich zakupów”. Zakupów, które od podobnych działań wyróżniał ich na poły legalny (a z pewnością jawny) charakter, organizacyjny rozmach, zainwestowane środki, a przede wszystkim poparcie kół rządowych.

\section{Bibliografia}

\section{Źródla archiwalne}

Archiwum Akt Nowych.

Kolekcja akt różnej proweniencji, sygn. 1/122.

Komisja Specjalna do Walki z Nadużyciami i Szkodnictwem Gospodarczym, sygn. 107. Komitet Centralny Polskiej Partii Robotniczej, sygn. 295/VII - 256.

Ministerstwo Administracji Publicznej, sygn. 2391.

Archiwum Instytutu Pamięci Narodowej w Szczecinie, sygn. 008/34, t. 1-2.

Archiwum Ministerstwa Spraw Zagranicznych.

Biuro Spraw Kongresowych, z. 18, w. 27, t. 411.

Archiwum Państwowe w Szczecinie.

\footnotetext{
${ }^{76}$ A. Zawistowski, Trzy próby walki z nierównowaga w handlu detalicznym. Trzy okresy reglamentacji artykułów pierwszej potrzeby w Polsce Ludowej, „Kwartalnik Kolegium Ekonomiczno-Społecznego. Studia i Prace" 2011, nr 3, s. 106-111.

${ }^{77}$ M. Zaremba, Wielka trwoga. Polska 1944-1947. Ludowa reakcja na kryzys, Kraków 2012, s. 535.

${ }^{78}$ Warto zaznaczyć, że i w latach późniejszych „system dystrybucji dóbr w warunkach realnego socjalizmu pozostawiał dużo miejsca na rozmaite nieformalne zabiegi i przetargi". M. Jastrząb, Paternalizm i klientelizm w Polsce Ludowej. Na przykładzie dystrybucji samochodów, „Annales Universitatis Paedagogicae Cracoviensis Studia Politologica” 2013, nr X, s. 77.
}

${ }^{79}$ H. Wilk, Między pragmatyzmem..., s. 69. 
Komisja Specjalna do Walki z Nadużyciami i Szkodnictwem Gospodarczym, Delegatura w Szczecinie: sygn. 69; sygn. 79.

Komitet Wojewódzki Polskiej Partii Robotniczej w Szczecinie: sygn. 10; sygn. 34.

Urząd Wojewódzki Szczeciński: sygn. 4891; sygn. 4895; sygn. 4899.

Archiwum Straży Granicznej.

Pomorska Brygada WOP, sygn. 180/7.

\section{Dokumenty publikowane}

Pierwszy wojewoda szczeciński. Dokumenty i komentarze (1945-1949), oprac. Z. Chmielewski, K. Kozłowski, Szczecin 1986.

Polska - Niemcy Wschodnie. Wybór dokumentów, t. 1: Polska wobec Radzieckiej Strefy Okupacyjnej Niemiec maj 1945 - październik 1949, red. J. Kochanowski, K. Ziemer, wstęp i wybór J. Kochanowski, oprac. A. Krajewski, M. Mazurek, Warszawa 2006.

Sektor prywatny, spółdzielczy oraz państwowy na Pomorzu Zachodnim w latach 19451949 w świetle sprawozdań Narodowego Banku Polskiego, wstęp, wybór i oprac. P. Chrobak, „Źródła do Dziejów Pomorza Zachodniego”, t. XVI, Szczecin 2015.

\section{Literatura}

Bagieński W., Wywiad cywilny Polski Ludowej w latach 1945-1961, t. 2, Warszawa 2017. Banaś K., Władysław Wolski. Meandry kariery komunistycznego działacza, Łódź 2019.

Białecki T., Wytyczenie granicy państwowej na zachód od Szczecina i Świnoujścia w 1945 roku, „Acta Cassubiana” 2006, nr 8.

Furtak R., Reformy pieniężne w Polsce w latach 1944-1950, „Annales Universitatis Mariae Curie-Skłodowska. Sectio H, Oeconomia” 1995/1996, nr 29/30.

Jastrząb M., Paternalizm i klientelizm w Polsce Ludowej. Na przykładzie dystrybucji samochodów, „Annales Universitatis Paedagogicae Cracoviensis Studia Politologica” 2013, nr X.

Kochanowski J., W polskiej niewoli. Niemieccy jeńcy wojenni w Polsce 1945-1950, Warszawa 2001.

Kochanowski J., Zanim powstała NRD. Polska wobec radzieckiej strefy okupacyjnej Niemiec 1945-1949, Wrocław 2008.

Kochanowski J., Tylnymi drzwiami. „Czarny rynek” w Polsce 1944-1989, Warszawa 2015.

Landau Z., Reformy walutowe na ziemiach polskich w 1945 roku, „Kwartalnik Historyczny" 1968, nr 1.

Macholak J., Delegatura Komisji Specjalnej do Walki z Nadużciami i Szkodnictwem Gospodarczym w Szczecinie 1946-1954. Organizacja i działalność, w: Działalność 
Delegatury Komisji Specjalnej do Walki z Nadużyciami i Szkodnictwem Gospodarczym w Szczecinie w latach 1945-1954. Materiały z konferencji naukowej z 20 marca 1998 r., red. Z. Chmielewski. Szczecin 1998.

Marczak T., Granica zachodnia w polskiej polityce zagranicznej w latach 1944-1950, Wrocław 1995.

Prochwicz J., Organizacja Wojsk Ochrony Pogranicza wrzesień 1945 - grudzień 1945, „Biuletyn. Problemy Ochrony Granic” 2010, nr 44.

Rembacka K., Wykluczony, skarcony, zmarginalizowany? Załamanie kariery politycznej Leonarda Borkowicza w 1950 roku - studium przypadku, w: Elity komunistyczne w Polsce, red. M. Szumiło, M. Żukowski, Warszawa-Lublin 2015.

Rembacka K., Leonard Borkowicz (1912-1989). Biografia polityczna, praca doktorska napisana pod kierunkiem prof. J. Eislera w Instytucie Historii Polskiej Akademii Nauk, Warszawa 2019, mps.

Rutkowski T.P., Sprawa Antoniego Piwowarczyka - Władysława Wolskiego, „Zeszyty Historyczne "2005, z. 153.

Sitarz B., Trudne początki. Powiat szczeciński 1945-1950, Police 2012.

Stefaniak M., Działalność aparatu represji na zachodnim pograniczu Polski $w$ latach 1945-1950, Szczecin 2008.

Wilk H., Między pragmatyzmem a oczekiwaniami. Społeczeństwo, władza i samochody w Polsce 1945-1970, Warszawa 2017.

Zaremba M., Wielka trwoga. Polska 1944-1947. Ludowa reakcja na kryzys, Kraków 2012.

Zaremba P., Pierwszy szczeciński rok 1945, Poznań 1970.

Zaremba P., Dziennik 1945, Szczecin 1996.

Zawistowski A., Trzy próby walki z nierównowaga w handlu detalicznym. Trzy okresy reglamentacji artykułów pierwszej potrzeby w Polsce Ludowej, „Kwartalnik Kolegium Ekonomiczno-Społecznego. Studia i Prace” 2011, nr 3.

Żukowski M., Działalność i organizacja Delegatury Komisji Specjalnej do Walki z Nadużyciami i Szkodnictwem Gospodarczym w Szczecinie oraz Koszalinie w latach 1946-1954, „Przegląd Zachodniopomorski” 2002, nr 2.

\section{Abstrakt}

$\mathrm{W}$ artykule podjęto zagadnienie powojennych zakupów prowadzonych przez polskich urzędników w Berlinie, których celem było ściąganie deficytowych towarów, w tym samochodów. Przedstawiono mechanizm jaki towarzyszył „,berlińskim zakupom” - zaprezentowani zostali pomysłodawcy i uczestnicy akcji oraz urzędy i służby w nich partycypujące bądź je kontrolujące. Podjęto również próbę oceny zjawiska i jego skali. 


\title{
Shortages of 1945 and the West Pomeranian ideas to overcome them. The question of the 'Berlin Purchases'
}

\begin{abstract}
The article presents the question of the post-war purchases made by Polish clerks in Berlin. The intention behind those purchases was to fill the gap on the Polish market, especially as far as cars are concerned. The mechanism of those purchases was described, together with the originators and participants and the offices and services that took part in the action or controlled it. The article also contains an appraisal of that action and depicts its scale.
\end{abstract}

